African Journal of Biomedical Research, Vol. 10 (2007); 145 - 151

ISSN 1119 - 5096 @ Ibadan Biomedical Communications Group

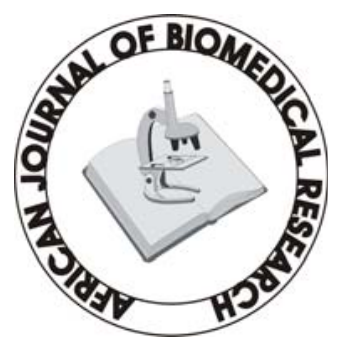

Full-text available at http://www.ajbrui.com http://www.bioline.br/md http://www.ajol.com

Received:

January 2007

Accepted (Revised): April 2007

Published May 2007
Full Length Research Article

\section{Acid secretory response and electrolyte composition of gastric juice in Diabetic rats}

\author{
${ }^{1}$ Elsie O. Adewoye, ${ }^{1}$ Samuel B Olaleye and ${ }^{2}$ Abayomi O. Ige \\ ${ }^{1}$ Department of Physiology, College of Medicine, University of Ibadan, \\ Ibadan \\ ${ }^{2}$ Department of Physiology, College of Medicine, Enugu State University of \\ Science and Technology, Enugu
}

\begin{abstract}
This study was designed to investigate gastric acid secretion and electrolyte composition in diabetic rats. 60 male rats of Wister strain weighing between 200 - $260 \mathrm{~g}$ were used for the study. Diabetes was induced with $65 \mathrm{mg} / \mathrm{kgbw}$ alloxan intravenously and confirmed with a constant blood glucose level $\geq 200 \mathrm{mg} / \mathrm{dl}$. Acid secretion was measured using the continuous perfusion method. Gastric juice was collected through a duodenal cannular attached to the pyloric ligation and its electrolyte composition was determined. Basal acid secretion was collected in aliquots every 10minutes for a period of 50minutes Histamine $(10 \mathrm{mg} / \mathrm{kgbw})$ was injected intramuscularly into the histamine group and carbachol (20 $\mathrm{gg} / \mathrm{kgbw})$ was injected intramuscularly into the carbachol group to stimulate acid secretion. Stimulated acid secretion was collected for 50 minutes at 10 minutes interval. There were significant reductions $(p<0.001)$ in the basal acid secretion of the diabetic rats compared to the controls. Acid secretory response to histamine and carbachol in the test groups were also significantly reduced $(p<0.001)$. The electrolyte composition $\left(\mathrm{Na}^{+}, \mathrm{K}^{+}, \mathrm{HCO}_{3}^{-}\right)$of gastric juice in the diabetic rats were significantly reduced $(p<0.01)$. There was no difference in $\mathrm{Cl}^{-}$concentration of gastric juice in diabetic group compared with controls. The reduced gastric secretory output observed in the study could possibly be due to impairment of the neural pathways mediating acid secretion. The altered electrolyte composition of gastric juice observed in the diabetic groups could possibly be attributed to changes in the extracellular fluid caused by diabetes mellitus.
\end{abstract}

(Afr. J. Biomed. Res. 10: 145 - 151)

Keywords: Acid Secretion, Electrolytes, Gastric Juice, Alloxan, Diabetes Mellitus

*Address for Correspondence (e-mail): elolade@yahoo.com

Abstracted by:

African Index Medicus (WHO), CAB Abstracts, Index Copernicus, Global Health Abstracts, Asian Science Index, Index Veterinarius, Bioline International , African Journals online 


\section{INTRODUCTION}

Gastrointestinal disorders are common pathological features in animals and man. Acute and chronic hyperglycemia has been reported to have led to specific gastrointestinal complications (Yang, 1984; Zelechowski et al, 1997); which include decreased intestinal motility (De Block et al, 2002) and abnormal postprandial motor activity (Camillieri et al, 1984).

Reports on the response of the parietal cells in diabetes are observed to be conflicting and inconclusive. The response of parietal cells to histamine has been reported to be impaired in diabetes mellitus (Mehta et al, 1993) whereas Tashima et al (2000) reported that the acid secretory response to histamine was unchanged in diabetes mellitus. In addition the histamine stimulated acid secretory output has also been reported to be reduced (Ozcelikay et al, 1993) in diabetes mellitus. Nabavizadeh et al (2004) also reported that though diabetes affects gastric secretion its exact effect has not been fully understood.

Though histamine stimulation of acid secretion in diabetes has been reported (Mehta et al, 1993; Ozcelikay et al, 1993; Tashima et al 2000). There is a dearth of information on the effect of carbachol stimulation of acid secretion in alloxan induced diabetes mellitus and the effect of diabetes on the electrolyte composition of gastric juice in rats.

This study was therefore designed to investigate the acid secretory response of diabetic rats to both histamine and carbachol stimulation and to investigate the effect of diabetes on the electrolyte composition of gastric juice in the rat.

\section{MATERIALS AND METHODS}

60 male albino rats of Wister strain weighing between 200 - 260g were used in this study. The animals were fed with standard rat chow obtained from Ladokun feeds, Ibadan and allowed free access to drinking water. They were randomly picked and divided into 2 groups (Control group and the diabetic group) with 30 rats in each group.

The control and the diabetic groups were divided into 3 subgroups with 10 rats in each subgroup. Subgroup 1 was treated with histamine; subgroup 2 was treated with carbachol and subgroup 3 was used for electrolyte evaluation.

\section{Reagents Used}

Histamine was obtained from BDH laboratories, Cimetidine from Apotex NZ Ltd, Auckland, carbachol salt from Sigma laboratories, USA while atropine was purchased from Indus Pharma, Pakistan. All other reagents were of analytical grade and obtained from Sigma-Aldrich Inc (St. Louis, MO, USA), unless otherwise stated

\section{Induction of Diabetes}

Animals in the diabetic group were fasted for 24hours before inducing diabetes since hyperglycemia has been reported to inhibit alloxan induction of diabetes (Szkuldelski et al 2001). 100mg of alloxan granules (BDH laboratories, USA) were dissolved in $1 \mathrm{ml}$ of normal saline $(0.9 \% \mathrm{NaCl})$ to make a $100 \mathrm{mg} / \mathrm{ml}$ solution. A single dose of $65 \mathrm{mg} / \mathrm{kg}$ body weight alloxan was administered intravenously to the animals to induce diabetes (Szkudelski et al 2001). Diabetes was confirmed 48hours after alloxan injection with a glucometer (Prestige $^{\mathrm{tm}}$ ). The blood glucose level was observed for 5 days. Rats with consistent blood glucose level greater than $200 \mathrm{mg} / \mathrm{dl}$ was taken as diabetic.

\section{Measurement of Gastric secretion}

Animals were fasted for 24hours to clear the stomach of all food materials. Acid secretion was measured using a modified Langerdoff apparatus (Amure and Ginsburg, 1964). Each animal was anaesthesized with $0.25 \mathrm{mg} / \mathrm{ml}$ urethane at a dose of $0.6 \mathrm{ml} / 100 \mathrm{~g}$ body weight. Esophageal cannular from Langerdoffs apparatus was inserted through the mouth of the anaesthetized rat into the stomach (Amure and Ginsburg, 1964).

Another cannular was inserted into the duodenal end of the stomach as described by Ghosh and Schild (1955). Perfusing fluid regulated at 37oC and flow rate of $0.5 \mathrm{mls} / \mathrm{min}$ was allowed to flow into the stomach through the esophageal cannular while the effluent was collected through the duodenal cannular. Effluents were collected in aliquots every 10 minutes and acid secretion was determined by titrating each sample of gastric effluent against 
$0.0025 \mathrm{~N} \mathrm{NaOH}$. The level of acidity in each sample was calculated.

\section{Analysis of Electrolyte composition}

Gastric juice was also collected through the cannular from the pyloric ligation in aliquots at 10minutes interval for 50minutes. The electrolyte composition of the gastric effluents collected was analyzed using an Easylyte electrolyte analyzer (Medica Electrolyte Analyzer, K127, Bedford). $\mathrm{Na}^{+}$, $\mathrm{K}^{+}, \mathrm{HCO}_{3}{ }^{-}$and $\mathrm{Cl}^{-}$composition were analyzed.

\section{Acid secretory response to Histamine stimulation}

The perfusate from the Langerdoff apparatus was allowed to run through the stomach and effluents where collected in aliquots for 50 minutes at 10 minutes interval to ensure a constant basal level of acidity. Atropine ( $5 \mathrm{mg} / \mathrm{kgbw}$ ) was thereafter injected through the gastrocnemius muscles of the animals in order to block acid stimulation via $\mathrm{M}_{3}$ receptors. 2 minutes after atropine injection, histamine (10mg/kgbw) was administered through the gastrocnemius muscles to stimulate gastric acid secretion and effluents were collected in aliquots at 10 minutes interval for 50 minutes. Level of acidity in each sample collected was determined by titrating each sample of effluent with $0.0025 \mathrm{~N} \mathrm{NaOH}$.

Acid secretory response to Carbachol stimulation

The perfusate was allowed to run through the stomach and effluents were collected in aliquots at 10 minutes interval until a constant basal level of acidity was obtained. The level of acidity became consistent within 50minutes. Cimetidine (40mg/kgbw) was then administered through the gastrocnemius muscles of the animals in order to inhibit acid stimulation via $\mathrm{H}_{2}$ receptors. After about 2 minutes, Carbachol (10mg/kgbw) was administered through the gastrocnemius muscles and effluents were collected in aliquots at 10 minutes interval for 50 minutes. Level of acidity in each sample collected was determined by titrating each sample of effluent with $0.0025 \mathrm{~N} \mathrm{NaOH}$.

\section{Statistical analysis}

The values were recorded as mean \pm SEM. Student $t$ test was used to assess the statistical significance of results obtained between the two groups. Confidence interval of $95 \%$ was taken as statistically significant.

\section{RESULTS}

\section{Basal and Histamine Stimulated Acid Output}

The basal and histamine stimulated $(10 \mathrm{mg} / \mathrm{kg})$ acid secretion in control and diabetic rats are shown in figure 1. The basal acid secretion in the control group was $0.51 \pm 0.033 \mathrm{mEq} / \mathrm{L}$ while that in the diabetic group was $0.37 \pm 0.027 \mathrm{mEq} / \mathrm{L}$. This shows a reduction of $25.5 \%$ in basal acid output in the diabetic animals $(\mathrm{P}<0.001)$ when compared with the control animals. The stimulatory effects of histamine caused the acid secretory rate to rise to $0.90 \pm 0.047$ $\mathrm{mEq} / \mathrm{L}$ in the control group and $0.47 \pm 0.029 \mathrm{mEq} / \mathrm{L}$ in the diabetic group. Thus histamine caused a $76.5 \%$ increase in acid output in the control and a $27.0 \%$ increase in output in the diabetic group. This shows that there was a significant reduction in histamine stimulated acid output in the diabetic animals $(\mathrm{P}<0.001)$.

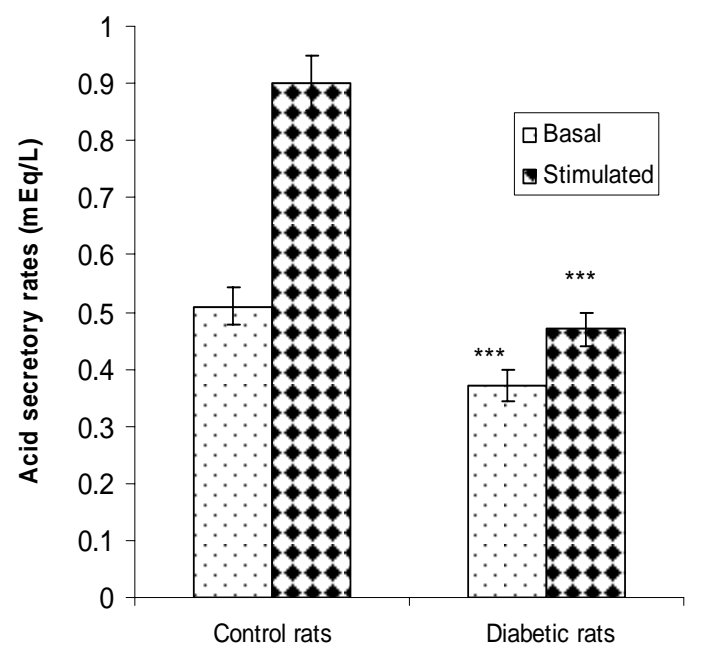

$$
\begin{gathered}
\text { Fig } 1 \text { Basal and Histamine stimulated }(10 \mathrm{mg} / \mathrm{kg}) \text { acid } \\
\text { secretion in control and diabetic rats } \\
\text { *** significant difference }(\mathrm{p}<0.001) \text { observed between } \\
\text { groups }
\end{gathered}
$$

Basal and Carbachol Stimulated Acid Output Figure 2 shows the basal and carbachol stimulated $(20 \mu \mathrm{g} / \mathrm{kg})$ acid secretion in control and diabetic rats. The basal acid secretion in the control group was $0.50 \pm 0.025 \mathrm{mEq} / \mathrm{L}$ while that in the diabetic group 
was $0.33 \pm 0.026 \mathrm{mEq} / \mathrm{L}$. This shows a reduction of $34 \%$ in basal acid output in the diabetic animals $(\mathrm{P}<0.001)$ when compared with the control animals. The stimulatory effects of carbachol caused the acid secretory rate to rise to $0.77 \pm 0.048 \mathrm{mEq} / \mathrm{L}$ in the control group and $0.45 \pm 0.024 \mathrm{mEq} / \mathrm{L}$ in the diabetic group. Thus carbachol caused a $54.0 \%$ increase in acid output in the control and a $36.4 \%$ increase in output in the diabetic group. This shows a significant reduction in carbachol stimulated acid output in the diabetic animals $(\mathrm{P}<0.001)$.

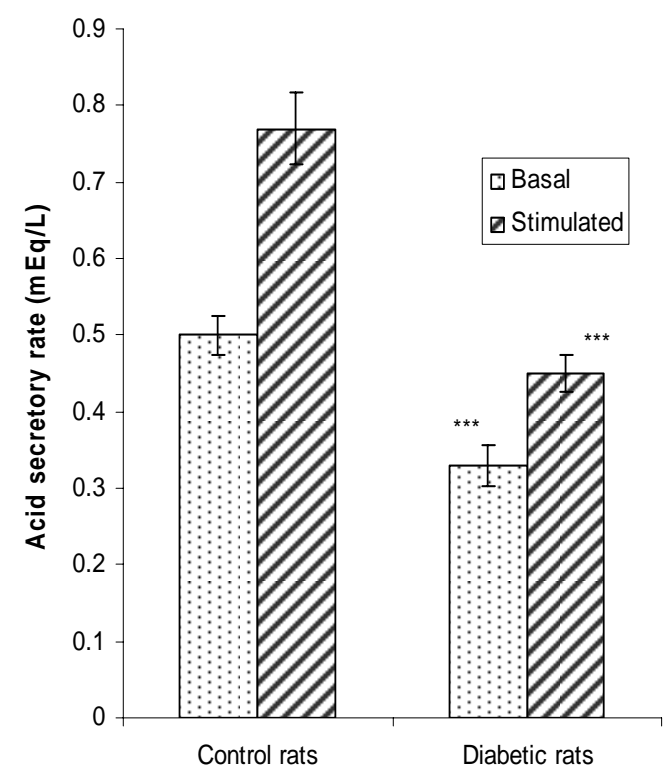

Fig 2. Basal and Carbachol stimulated (20ug/kg) acid secretion in control and diabetic rats *** significant difference $(p<0.001)$ observed between groups

\section{Electrolyte Composition of Gastric Juice}

Table 1 shows the electrolyte composition of gastric juice $\left(\mathrm{Na}^{+}, \mathrm{K}^{+} \mathrm{Cl}^{-}, \mathrm{HCO}_{3}^{-}\right)$in normal and diabetic rats. Data is shown as mean \pm SEM.

The results obtained from the analysis of the electrolyte composition of gastric juice $\left(\mathrm{Na}^{+}, \mathrm{K}^{+}\right.$, $\mathrm{HCO}_{3}{ }^{-}$and $\mathrm{Cl}^{-}$) showed a $32.4 \%$ reduction in $\mathrm{Na}^{+}$ concentration of gastric juice collected from the diabetic rats $(\mathrm{P}<0.01)$. There was also a $60 \%$ reduction in $\mathrm{K}^{+}$concentration of gastric juice in the diabetic rats $(\mathrm{P}<0.01)$. There was no significant reduction in $\mathrm{Cl}^{-}$concentration in the diabetic rats. The $\mathrm{HCO}_{3}{ }^{-}$concentration of gastric juice in the diabetic rats was significantly reduced $(\mathrm{P}<0.01)$.
Table 1

Electrolyte composition of gastric juice $\left(\mathrm{Na}^{+}, \mathrm{K}^{+} \mathrm{Cl}^{-}\right.$, $\mathrm{HCO}_{3}^{-}$) in normal and diabetic rats. Data is shown as mean \pm SEM.

\begin{tabular}{ccc}
\hline Electrolytes & $\begin{array}{c}\text { Control group } \\
(\mathbf{m m o l} / \mathbf{L})\end{array}$ & $\begin{array}{c}\text { Diabetic group } \\
(\mathbf{m m o l} / \mathbf{L})\end{array}$ \\
\hline $\mathrm{Na}^{+}$ & $10.94 \pm 1.15$ & $7.4 \pm 0.31^{*}$ \\
\hline $\mathrm{K}^{+}$ & $0.7 \pm 0.084$ & $0.28 \pm 0.020^{*}$ \\
\hline $\mathrm{Cl}^{-}$ & $8.4 \pm 0.75$ & $7.6 \pm 0.75$ \\
\hline $\mathrm{HCO}_{3}^{-}$ & $4.4 \pm 0.50$ & $2.4 \pm 0.25^{*}$ \\
\hline $\begin{array}{l}\text { number of animals in each group }=10 \\
*= \\
\text { groups }\end{array}$ &
\end{tabular}

\section{DISCUSSION}

Diabetes mellitus has been reported to produce several symptoms related to gastroenterology (Vogt et al, 1999). Perusicova (2004) reported that the impaired function of the gastrointestinal tract related to diabetes mellitus results from diabetic autonomic neuropathy, impaired sensory innervation and a direct effect of chronic hyperglycemia. A reduction in histamine stimulated acid output was observed in the diabetic group and this is consistent with the work of Ozcelikay et al (1993) who reported decrease in histamine induced acid secretion in the diabetic rat. This is also corroborated by Mehta et al (1993) who reported severe impairment in the secretory response of parietal cells in diabetes mellitus. Carbachol stimulated acid output was also observed to be reduced in the diabetic group when compared with the control group.

Tashima et al (2000) however reported results which are contrary to the results obtained in this study and to those of Ozcelikay et al (1993) and Mehta et al (1993). He observed no response to histamine stimulation while the response to carbachol was enhanced in streptozotocin diabetic rats. The observed differences could possibly be connected to type of drug, the route of drug administration, rate of metabolism of the drug, metabolites produced (Zysset and Somer, 1986) and duration of diabetes induction (Hernandes et al, 2000).

Though the exact onset of diabetic 
complications is unknown, it is often linked to the level of control of the diabetic state. Prolonged hyperglycemia has therefore been reported to lead to peripheral nerve damage due to metabolic or osmotic damage to neurons or Schwann cells (Skyler, 1996). In nerves and neurons, glucose is converted by the enzyme aldose reductase to sorbitol (Tiwari and Madhusudana, 2002); in diabetes, a major abnormality in the nerve is the accumulation of sorbitol because of the increased influx in the polyol pathway secondary to hyperglycemia (Tomlinson, 1999) and this has been reported to cause an increase in intracellular osmolarity leading to deleterious effects on neural metabolism (Warkin and Thomas, 1999). These effects eventually lead to reduced nerve myoinositol, decreased membrane $\mathrm{Na}+/ \mathrm{K}+-$ ATPase activity, impaired axonal transport, and structural breakdown of nerves, causing abnormal action potential propagation (Sima et al, 1988) and reduced neuronal transmission (Greene $e t$ al, 1999).

It is known that gastric acid secretion is mediated through an interplay of neurons and neuronal fibers that originate from both the enteric nervous system (ENS) and the central nervous system (CNS). Histamine has been reported to stimulate acid secretion through $\mathrm{H}_{2}$ receptors and carbachol $\mathrm{M}_{3}$ receptors. By blocking $\mathrm{M}_{3}$ receptor stimulation before stimulating acid secretion with histamine this study has demonstrate that alloxan induced diabetes most likely affects $\mathrm{H}_{2}$ receptors. In addition, by blocking $\mathrm{H}_{2}$ receptor stimulation before stimulating acid secretion with carbachol this study has demonstrated that alloxan induced diabetes also affects $\mathrm{M}_{3}$ receptors.

It is therefore possible that uncontrolled hyperglycemia as observed in alloxan induced diabetes may have affected the neural pathways involved in gastric acid secretion. This may therefore account for the reduction in basal and stimulated acid output of the diabetic animals observed in this study.

Gastric juice can be described as a mixture of secretions from parietal cells and non-parietal cells. With respect to the secretion of electrolytes, it may be described as electrolyte secretions from the parietal cells and non-parietal cells. When acid is being secreted at basal levels i.e. with no stimulation, the juice is primarily made up of $\mathrm{Na}^{+}$, $\mathrm{Cl}^{-}$with very little $\mathrm{H}^{+}$secretion (Guyton and Hall, 2000). As the rate of secretion increases the amount of $\mathrm{Na}^{+}$secreted from the parietal cells drops, and the amount of $\mathrm{H}^{+}$and $\mathrm{Cl}^{-}$increases. $\mathrm{K}^{+}$secretion rates stay relatively constant irrespective of the rate of secretion. The basal secretion of non-parietal cells is essentially $\mathrm{Na}^{+}$and $\mathrm{Cl}^{-}$, with $\mathrm{K}^{+}$at about the same concentration as in plasma, and a bit of $\mathrm{HCO}_{3}{ }^{-}$. As the rate of gastric secretion begins to increase the concentrations of ions in gastric juice approach that of pure parietal secretion.

In this study, it was observed that there was a significant reduction in $\mathrm{Na}^{+}, \mathrm{K}^{+}$and $\mathrm{HCO}_{3}{ }^{-}$content of gastric juice in the diabetic rats. The secretion of electrolytes from the parietal and non-parietal cells is dependent on the constant exchange of electrolytes between the intracellular fluids (ICF) of these cells and the extracellular fluid (ECF) (Pitts, 1974). Thus a depletion of electrolytes in the ECF will likely affect the ICF concentration of electrolytes of the parietal and non-parietal cells that both contribute to the electrolyte composition of gastric juice.

In diabetes, large increase in plasma glucose causes cell dehydration and movement of $\mathrm{K}^{+}$from cells into the extracellular fluid (ECF). The increased $\mathrm{K}^{+}$in the ECF causes an increase in the activity of the P-cells of the distal and cortical collecting tubules which leads to increased renal excretion of $\mathrm{K}^{+}$(Yared et al, 2003). It has also been reported that glucosuria as observed in diabetes also leads to the excretion of excess water, $\mathrm{Na}^{+}$and $\mathrm{K}^{+}$in urine (Matz, 1999). It is therefore possible that the electrolyte and water loss usually observed in diabetes would lead to a depletion of ECF electrolytes and this could therefore affect the secretion of electrolytes by the parietal and nonparietal cells. This may therefore account for the significant reduction in $\mathrm{Na}^{+}$and $\mathrm{K}^{+}$content of gastric juice observed in the diabetic rats when compared with the control in this study.

Hyperglycemia as seen in uncontrolled diabetes is known to result in metabolic acidosis (Stoner, 2005) which causes an increase in respiratory activities and these leads to an increase in the loss of $\mathrm{CO}_{2}$ from the blood. The loss of $\mathrm{CO}_{2}$ from the blood leads to a reduction in $\mathrm{HCO}_{3}{ }^{-}$concentration of the 
ECF. This loss of $\mathrm{HCO}_{3}{ }^{-}$from the ECF may be responsible for the significant reduction in $\mathrm{HCO}_{3}{ }^{-}$ content of gastric juice observed in the diabetic animals.

In the ECF, an inverse relationship is known to exist between $\mathrm{HCO}_{3}{ }^{-}$and $\mathrm{Cl}^{-}$in order to keep anion concentration constant, thus a decrease in $\mathrm{HCO}_{3}{ }^{-}$ concentration of the ECF will likely cause an increase in $\mathrm{Cl}^{-}$concentration (Guyton and Hall, 2000). This increase in ECF $\mathrm{Cl}^{-}$concentration may therefore account for the insignificant difference $(\mathrm{P}>0.05)$ in $\mathrm{Cl}^{-}$concentration of gastric juice observed in the diabetic animals.

It could therefore be concluded from this study that in alloxan induced diabetic rats there is a decrease in both basal and stimulated (histamine/carbachol) acid secretion. This reduction may possibly be mediated through $\mathrm{H}_{2}$ and $\mathrm{M}_{3}$ receptors. There is a possibility that diabetes caused impairment in the sensitivity of the neural pathway that mediates acid secretion.

This study also shows that there was a significant reduction in the $\mathrm{Na}^{+}, \mathrm{K}^{+}$and $\mathrm{HCO}_{3}^{-}$content of gastric juice secreted by the stomach of the diabetic animal which could be attributed to alteration in the ECF caused by diabetes mellitus.

\section{REFERENCES}

Amure BO, Ginsburg M (1964): Inhibitors of Histamine catabolism and the action of gastrin in the rat. Br J Pharmacol Chemother; 23:476-485.

Camillieri M and Malagelada JR (1984): Abnormal intestinal motility in diabetes with gatroparesis syndrome. Journal of clinical investigations; 14: 420-427.

De Block CEM, De Leeuw IH, Pelckmans PA (2002): Delayed gastric empyting and gastric motility in type1 diabetes. Care; 25 (5): 912 - 917. Enyikwola O. (1994): Effects of guinea pepper (Aframomum melegueta) on gastric acid secretion in albino rats. International Journal of Pharmacognosy; 32(1): 37-43.

Ghosh MN and Schild HO (1955): A method for the continuous recording of acid gastric section in the rat. Am. J. Physiol; 128(2):35-6P.

Greene DA, Arezzo JC, Brown MB (1999): Effect of aldose reductase inhibition on nerve conduction and morphometry in diabetic neuropathy. Zenarestat Study Group. Neurology; 53(3): 580-591

Guyton CA and Hall JE (2000): Textbook of Medical Physiology, $10^{\text {th }}$ edition: Sanders company, Philadelphia. pp894 - 897.

Hernandes L, Bazotte R, Gama P, De MirandaNeto MH (2000): Streptozotocin-induced diabetes duration is important to determine changes in the numberand basophily of myenteric neurons Arq Neuropsiquiatr; 58(4):1035-1039

Matz R (1999): Management of the Hyperosmolar Hyperglycemic Syndrome. Am Fam Physician; 60:1468-1476.

Mehta N, Veliath S, Thombre D.P (1993): The effect of bilateral gatric vagotomy and histamine stimulation on parietal cell activity in streptozotocin induced diabetes rat model. Indian J. Physiol. Pharmacol; 37(1)30-34.

Nabavizadeh Rafsanjani F, Vahedian J (2004): The effect of insulin-dependent diabetes mellitus on basal and distention-induced acid and pepsin secretion in rat. Diabetes Res Clin Pract.; 66(1):1-6. Ozcelikay VM, Altan YM, Yildizoglu-Ari N, Altinkurt O, Onur F, Ozturk Y (1993): Basal and histamine-induced gastric acid secretion in alloxan diabetic rats. Gen Pharmacol; 24(1): 121- 126.

Perusicova J (2004): Gastrointestinal complications in diabetes mellitus. Vnitr Lek; 50(5):338- 343.

Pitts RF (1974): Physiology of the Kidney and body fluids. $3^{\text {rd }}$ edition: Year book Medical publishers. Inc, Chicago: pp 11-34

Salim AS (1988): Gastric diversion or pylorus ligation for gastric mucosal integrity and acid secretion studies in the rat? Digestive Diseases and Sciences; 33(11):1441-1444.

Sima AA, Nathaniel V, Bril V, McEwen TA, and Greene DA (1988): Histopathological heterogeneity of neuropathy in insulin-dependent and non-insulin-dependent diabetes, and demonstration of axo-glial dysjunction in human diabetic neuropathy. J Clin Invest.; 81(2): 349-364. Skyler JS (1996): Diabetic complications. The importance of glucose control. Endocrinol Metab Clin North Am; 25(2): 243-254

Stoner GD (2005): Hyperosmolar hyperglycemic state. Am Fam Physician; 71:1723-1730

Suvitayavat W, Kodchawongs J, Thirawarapan Ss, Bunyapraphatsara N (2004): Effects of Ya- 
hom on the gastric secretion in rats. Journal of Ethnopharmacology; 94(2-3): 331-338

Szkudelski T (2001): The mechanism of alloxan and streptozotocin action in B cells of the rat pancreas. Physiol Res.; 50:536 - 546.

Tashima K, Nishijima M, Fujita D, Kobomi M, Takeuchi K (2000): Acid secretory changes in streptozocin diabetes rats: different response to various secretagogues. Dig Dis; 45 (7): 1352-1358. Tiwari AK, Madhusudana RJ (2002): Diabetes mellitus and multiple therapeutic approaches of phytochemicals: Present status and future prospects. Current science; 83 (1): 30 - 38

Tomlinson DR (1999): Role of aldose reducase inhibitors in the treatment of diabetic polyneuropathy. In: Dyke PJ, Thomas PK eds. Diabetic neuropathy. $2^{\text {nd }}$ ed. WB Saunders, Philadelphia: pp330 - 340.

Vogt M, Adamek HE, Arnold JC, Schilling D, Schleiffer T, Riemann JF (1999): Gastrointestinal complications of diabetes mellitus. Med Klin; 94(6):329-337.
Warkin PJ and Thomas PK (1999): Diabetic neuropathy: Mechanism and future treatment option. J. Neuro. Neurosurg and Psych.; 67: 277 - 281.

Yang M.J (1984): Gastrointestinal tract complications of diabetes mellitus. Pathophysiology and management. Arch Intern Med.; 144(6):12511256.

Yared Z, Chiasson JL (2003): Ketoacidosis and the hyperosmolar hyperglycemic state in adult diabetic patients. Diagnosis and treatment. Minerva Med.; 94(6):409-418.

Zelechowski M, Pokrzywnicki W, Trzepiora B, Gawlik B, Grzeszczak W (1997): Gastric motility disorders in diabetes. I. Pathophysiology, symptomatology and methods for additional testing. Wiad Lek.; 50 (1-3):32-38.

Zysset T. and Sommer L. (1986): Diabetes alters drug metabolism-in vivo studies in a streptozotozindiabetic rat model. Journal Cellular and Molecular Life Sciences; 42(5): 560 - 562. 